Article

\title{
Tree Shelterbelts as an Element to Improve Water Resource Management in Central Asia
}

\author{
Niels Thevs ${ }^{1, *}$, Eva Strenge ${ }^{2}$, Kumar Aliev ${ }^{1}$, Maksat Eraaliev ${ }^{3}$, Petra Lang ${ }^{2}$, Azim Baibagysov ${ }^{4}$ \\ and Jianchu $\mathrm{Xu}^{5}$ \\ 1 World Agroforestry Center, Central Asia Office, Bishkek 720001, Kyrgyzstan; K.Aliev@cgiar.org \\ 2 Faculty Regional and Environmental Sciences, University of Trier, 54286 Trier, Germany; \\ s6evstre@uni-trier.de (E.S.); langp@uni-trier.de (P.L.) \\ 3 Faculty of Social and Poöitical Sciences, German Kazakh University, Almaty 050010, Kazakhstan; \\ eraaliev@mail.ru \\ 4 Department of Biodiversity and Bioresources, Faculty of Biology and Biotechnology, al Farabi Kazakh \\ National University, Almaty 050040, Kazakhstan; azim.baibagysov@gmail.com \\ 5 Key Laboratory of Economic Plants and Biotechnology, Kunming Institute of Botany, Kunming 650201, \\ China; jxu@mail.kib.ac.cn \\ * Correspondence: N.Thevs@cgiar.org; Tel.: +996-771-771-993
}

Received: 24 August 2017; Accepted: 20 October 2017; Published: 31 October 2017

\begin{abstract}
In Central Asia, agriculture, notably irrigated agriculture, is the largest water consumer. Currently, flood and furrow irrigation are the dominant irrigation methods in Central Asia, in particular in the post-Soviet countries. Against the background of current and increasing competition for water-e.g., through reduced river runoffs in the course of climate change-water consumption of agriculture needs to be reduced. On the field plot level, improved irrigation technologies, like drip irrigation or plastic mulch, can reduce water consumption substantially. Alternatively, tree lines as wind breaks (shelterbelts) also can reduce crop water consumption, as shown by research from many drylands around the world. As previous research has concentrated on crop water consumption and not on tree water consumption, this paper brings the two together, in order to approach a more holistic picture, in how far shelterbelt systems, including the trees, may have the potential to save water or not. Crop water consumption was assessed through the Penman-Monteith approach for corn, wheat, potato, barley, and pear under open field conditions and under an assumed influence of a tree shelterbelt. Tree water consumption was investigated through sap flow measurements. Crop water consumption was reduced by $10-12 \%$ under influence of a shelterbelt compared to open field conditions. When water consumption of shelterbelts was added, a slight reduction of water consumption of the whole crop-shelterbelt system was found for corn, potato, and pear under the assumption 25 ha $(500 \times 500 \mathrm{~m})$ field sizes. Under an assumption of 4 ha $(200 \times 200 \mathrm{~m})$ field size, water consumption of the whole crop-shelterbelt system was higher for all crops investigated except for pear. The results suggest that shelterbelts may play a role in improving water resource management in Central Asia in the context of water demanding crops, like corn or cotton. In further research, other effects of shelterbelts, like increased crop yields and additional income from trees, need to be investigated.
\end{abstract}

Keywords: agroforestry; poplar; sap flow; evapo-transpiration; irrigated agriculture; Kyrgyzstan; Kazakhstan

\section{Introduction}

Central Asia, which extends from the Caspian Sea into Mongolia, is largely dominated by drylands and mountains [1]. Furthermore, Central Asia is the region with the worldwide highest number of endorheic or closed river basins, i.e., rivers that do not drain into the sea, but in an end-lake or inland 
delta [2]. The most well-known end-lake was the Aral Sea [3]. The desiccation of the Aral Sea-mostly due to irrigation water withdrawals-is known as one of the worst man-made environmental disasters; and scientists have warned that the "Aral Sea Syndrome" could repeat in other parts of the region [4]. Agriculture is concentrated along the rivers, e.g., along the Amu Darya, Syr Darya, Chui, or Talas and their tributaries as well as in the forelands of the mountain ranges, e.g., along the northern slopes of the Tianshan. Agriculture depends on irrigation due to the semi-arid to arid climate of the agricultural areas of the region. Agriculture also is the major water consumer all over Central Asia, which causes conflicts over water and competition for water between water users, like irrigated agriculture and natural ecosystems [5]. It is expected that water shortages and competition will be aggravated in the future in the course of climate change [6].

Currently, flood and furrow irrigation are the dominant irrigation methods in Central Asia, in particular in the post-Soviet countries. Against the background of current and increasing competition for water, water consumption of agriculture needs to be reduced. On field plot level, improved irrigation technologies, like drip irrigation or plastic mulch, can reduce water consumption substantially, as shown in Xinjiang, China [7,8].

Next to sheer technology driven approaches, sound crop selection and agroforestry systems also may help to reduce water consumption or improve water productivity in irrigated agriculture. Systems of tree lines along field plots, i.e., tree shelterbelt systems, are the most prominent agroforestry system in the irrigated agriculture of Central Asia. Such shelterbelts were promoted during Soviet Union times. After the collapse of the Soviet Union, shelterbelts were largely cut down, as people urgently needed fuel wood to compensate for the collapse of regular energy supplies.

Shelterbelts were widely reported to reduce water consumption (evapo-transpiration) of crops, help to increase crop yields, and help to increase soil moisture, as they trap snow $[9,10]$. Crop water consumption is reduced mainly as shelterbelts substantially reduce wind speed and to a minor extent as inside a shelterbelt system air temperature is lower and air humidity is higher than outside a shelterbelt system $[11,12]$. Shelterbelts reduced wind speed on the leeward side to almost zero within a distance of five times the shelterbelt tree height. Moving away from shelterbelt, wind speed increased to half and $70 \%$ of the open field wind speed at a distance of 15 to 20 times shelterbelt tree height and 25 to 30 times shelterbelt tree height, respectively [10]. In contrast, after [11] in a distance of 25 times shelterbelt height wind speed was only reduced by $10 \%$ compared to open field conditions. An overall wind speed reduction in shelterbelt systems of 36\% and a reduction of crop water consumption by 15 to $30 \%$ compared to non-shelterbelt conditions, respectively were proposed by [10,13], while [9] only proposed a reduction of crop water consumption by $15-20 \%$. Reduction of wind speed by $30-40 \%$ and a decrease of air temperature by $1{ }^{\circ} \mathrm{C}$ through the impact of shelterbelts was published by [14]. Reduction of evapotranspiration of $35-45 \%$ compared to open field conditions on the windward side of shelterbelts in the vicinity of less than $50 \mathrm{~m}$ from the shelterbelt was reported by [15]. On the leeward side, a noticeable reduction of evapotranspiration was found as far as $300 \mathrm{~m}$ at a tree height of 8-10 m. In addition, shelterbelts trapped snow so that 70-90 $\mathrm{mm}$ of soil moisture was added from snow melt compared to open field conditions $[9,15]$.

Apple yields increased by 50\% within a distance of five times the shelterbelt tree height [10]. Wheat yields and potato yields increased by $20-30 \%$ and $37 \%$, respectively, in a shelterbelt system in the Kazakh steppe compared to open field conditions [15]. Wheat yield increases of $15 \%$ in shelterbelt systems in Kazakhstan were found by [16]. In general, crop yields increased between 5 times to 15 times the shelterbelt tree height leeward of the given shelterbelt [9].

These agroforestry systems could help to reduce water that is consumed by agriculture and thus contribute to a more sustainable and climate change resilient water resource management in Central Asia and beyond.

However, literature so far has concentrated on reduction of water consumption of the crops, while water consumption of the shelterbelt trees has been neglected. Therefore, the general objective of this paper is to help clarify if shelterbelt systems can play a role to improve water resource management 
in Central Asia in the future. To accomplish that objective, we present a holistic approach to water consumption of shelterbelt systems based upon the integrated analyses of shelterbelt tree water consumption data and crop water consumption data.

\section{Materials and Methods}

\subsection{Study Region}

The study was carried out in the village Karasay Batyr, Korday County, in the upper Chui Valley in south-eastern Kazakhstan in 2016. The geographical position is $42.38^{\circ} \mathrm{N}$ and $75.66^{\circ}$ E. The elevation is $1095 \mathrm{~m}$ above sea level. The upper Chui Valley stretches from the villages of Karasay Batyr and Kemin, about 100 km east of Bishkek, to Bishkek, the capital of Kyrgyzstan.

During Soviet Union times, Karasay Batyr was a Kolhoz, which was specialized on fruit production, mainly apple and pear. Field plots were of an average size of $250 \times 250 \mathrm{~m}$ bordered by shelterbelts of poplars (Populus alba and P. nigra) on all four sides. Thus, the agricultural land in Karasay Batyr was structured by a $250 \times 250 \mathrm{~m}$ grid of shelterbelts.

Today, most of the field plots are grown with grassy vegetation and are cut once or twice a year for hay-making. The field plots, which are under cultivation, are planted with potato or corn. The field plot and shelterbelt structure of today is illustrated in Figure 1.

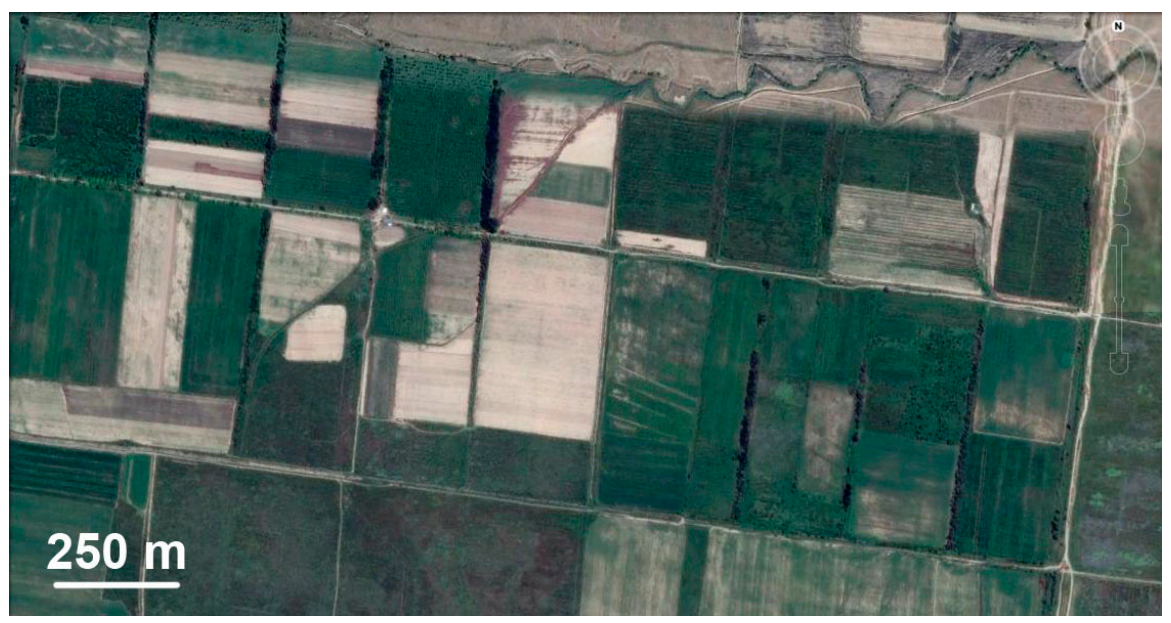

Figure 1. Field structure of Karasay Batyr as of 2016 (Google Earth).

The climate is continental and semi-arid with a rainy season in spring and hot, dry summers. The closest climate station is Tokmok (Table 1), which is $34 \mathrm{~km}$ from Karasy Batyr.

Table 1. Climatic features of Tokmok (https:/ / rp5.ru/Wetterarchiv_in_Tokmok). Data range from 2005 to 2016.

\begin{tabular}{cc}
\hline Climatic Feature & Tokmok Data \\
\hline Geographical position & $42.51^{\circ} \mathrm{N}, 75.18^{\circ} \mathrm{E}$ \\
Elevation [m a.s.l.] & 824 \\
Annual average temperature $\left[{ }^{\circ} \mathrm{C}\right]$ & 11.6 \\
January average temperature $\left[{ }^{\circ} \mathrm{C}\right]$ & -2.7 \\
July average temperature $\left[{ }^{\circ} \mathrm{C}\right]$ & 24.8 \\
Annual precipitation $[\mathrm{mm}]$ & 522 \\
Average wind speed in $10 \mathrm{~m}$ height $[\mathrm{m} / \mathrm{s}]$ & 1.2 \\
\hline
\end{tabular}

In the whole Chui Valley, in Kazakhstan and Kyrgyzstan, the major crops today are wheat, potato, corn, fodder plants, and on smaller areas fruit trees and barley (http:/ / www.fao.org/ag/agp/agpc/ 
doc/counprof/kyrgi.htm). Shelterbelt trees are poplars (Populus alba and P. nigra) in the more rainy and more intensively irrigated parts, while elm (mostly Ulmus minor) and Acacia species dominate on drier and less irrigated sites (own field observations and [17]).

\subsection{Water Consumption of Shelterbelt System vs. Non Shelterbelt System}

The methodological approach of this study was to assess water consumption of major crops of the Chui Valley under open field conditions with no shelterbelts present versus conditions as inside a shelterbelt system. These results are combined with water consumption of the trees of those shelterbelts, in order to obtain the water consumption of crops without shelterbelts versus corresponding crop-shelterbelt systems. Crop water consumption was assessed on the basis of climate data after [18], while tree water consumption was measured through sap flow measurements.

Karasy Batyr was taken as an example to represent the climate, crops, and water consumption conditions of the upper Chui Valley shared by Kyrgyzstan and Kazakhstan. In Karasay Batyr, a shelterbelt was chosen, which still was in good conditions, i.e., dominated by poplars $(P$. alba) instead of having a mix of tree species, trees of uniform height, not interrupted by gaps between trees, and continuous water supply to the trees (Figure 2).

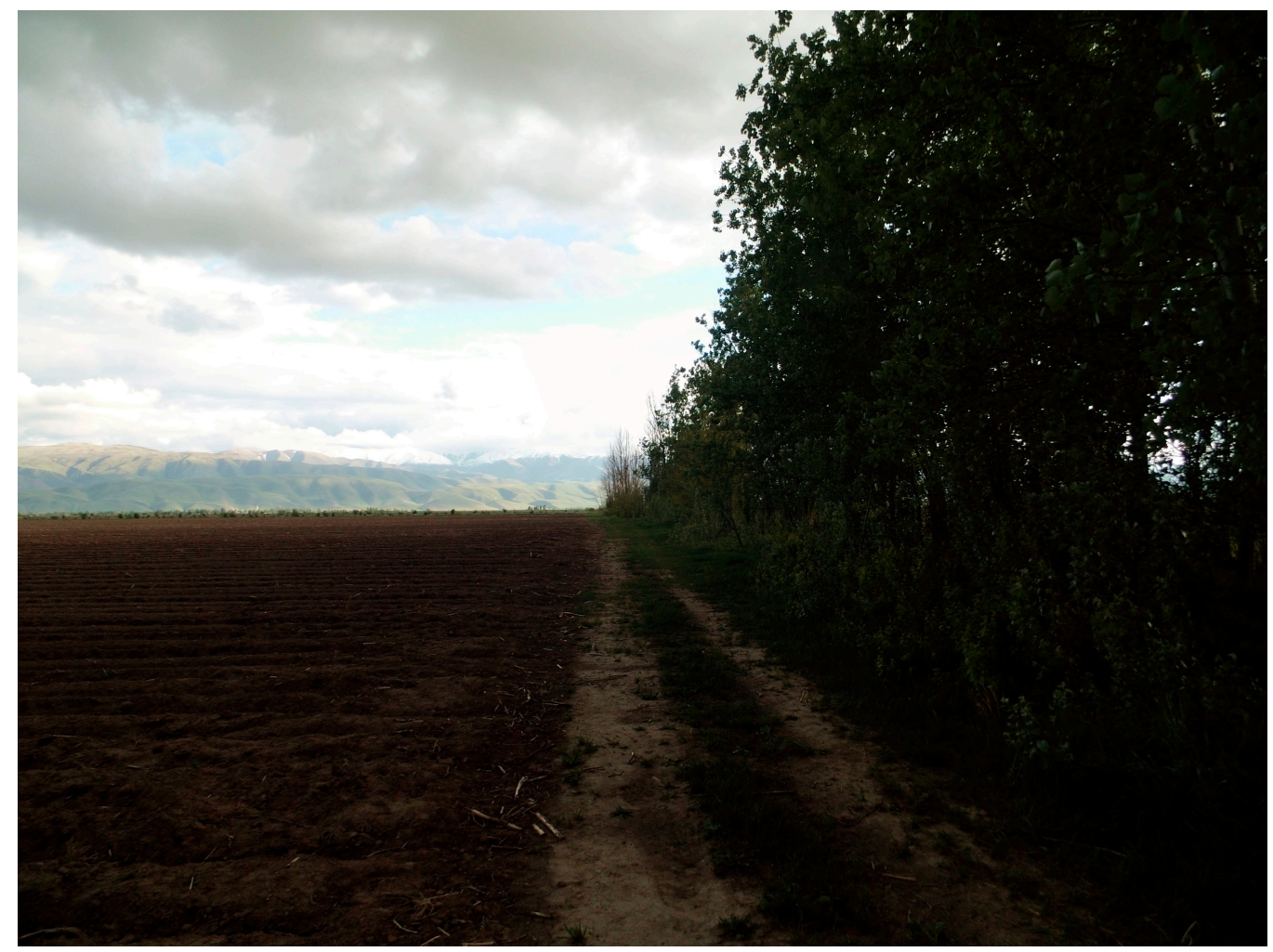

Figure 2. Shelterbelt in Karasay Batyr, where sap flow was measured during 2016, with neighboring potato field (photo Niels Thevs, April 2016).

From this shelterbelt, three representative poplars ( $P . a l b a$ ) were chosen (Table 2) for the sap flow measurements [19]. Sap flow was measured through the method of heat dissipation using the system PROSALOG by UP GmbH from Germany [20]. Thereby, a pair of sensor needles (2 cm long) was fixed into each tree at $140 \mathrm{~cm}$ and $150 \mathrm{~cm}$ tree height, respectively. The top needle released heat pulses into the sapwood every ten minutes. After each heat pulse, the temperature difference between both needles was measured. These temperature differences were calculated into sap flow density as follows [19]

$$
\mathrm{u}=0.714((\mathrm{dT} / \mathrm{dTmax})-1)^{1.231}
$$


$\mathrm{u}$-sap flow density $\left(\mathrm{mL} \mathrm{cm}^{-2} \mathrm{~min}^{-1}\right)$

dT-temperature difference between the two needles of one needle pair

$\mathrm{dTmax}$ - maximal dT, i.e., dT at zero sap flow

$\mathrm{dTmax}$ was chosen as the average temperature difference at the lowest water vapor pressure deficit over two-week periods. The average temperature difference was calculated from the temperature differences $20 \mathrm{~min}$ before to $20 \mathrm{~min}$ after the lowest water vapor pressure deficit of a given two-week time periods.

Sap flow density was calculated into sap flow by using the equation

$$
\varphi=\mathrm{u} S \mathrm{~A}
$$

$\varphi$ —sap flow $\left(\mathrm{mL} \mathrm{min}^{-1}\right)$

$\mathrm{u}$-sap flow density $\left(\mathrm{mL} \mathrm{cm}^{-2} \mathrm{~min}^{-1}\right)$

SA-sap wood area $\left(\mathrm{cm}^{2}\right)$

The xylem thickness, from which sap wood area was calculated, was determined visually from tree cores. On each tree two perpendicular cores were taken with a tree corer of $5 \mathrm{~mm}$ diameter from Suunto, Finland. Sap flow was recorded from 15 June until 3 August 2016.

Table 2. Data of the three sensor trees.

\begin{tabular}{cccccc}
\hline No. of Sensor Tree & $\begin{array}{c}\text { Diameter at Breast } \\
\text { Height (DBH) (cm) }\end{array}$ & Tree Height $(\mathbf{m})$ & Age (a) & $\begin{array}{c}\text { Average Xylem } \\
\text { Thickness }(\mathbf{c m})\end{array}$ & Sapwood Area $\left(\mathbf{c m}^{2}\right)$ \\
\hline 1 & 42.6 & 16 & 27 & 8.07 & 875 \\
2 & 19.2 & 16.4 & 14 & 3.8 & 183 \\
3 & 31.5 & 15.2 & 19 & 7.3 & 554 \\
\hline
\end{tabular}

Leafs started to emerge beginning of April and were fully developed by mid-April. Leafs turned yellow during October and fell completely down by 24 October. Therefore, the growing season for this study was defined as 1 April until 24 October.

Reference and crop evapo-transpiration (ETo and ETc) for conditions with and without shelterbelt were calculated after [18] for this growing season. Thereby, ETc was calculated for wheat, corn, potato, barley, and fruit trees (pear).

Outside of the reach of shelterbelts, a climate station was operated during parts of the growing season, in order not to conflict with farm operations. The climate station was equipped with the following sensors, all from Decagon Devices, USA: Sensor for air temperature and humidity (VP-4), radiation, and wind speed (DS-2 Anemometer). Data were logged by an EM-50 data logger. Climate data were recorded every minute and aggregated to daily values. Data gaps were filled by establishing relationships between air temperature, humidity, and wind speed between data measured at Tomok (https://rp5.ru/Wetterarchiv_in_Tokmok) and Karasay Batyr. Radiation for the data gaps was calculated as suggested by [18]. These filled daily climate data finally yielded ETo and ETc under conditions not influenced by any shelterbelt (open field conditions).

ETo and ETc of the above referred crops, under the influence of a shelterbelt, were assessed under the following assumptions:

Assumption I: Shelterbelts reduce wind speed by $20 \%$ of open field conditions.

Assumption II: Shelterbelts reduce wind speed by $35 \%$ of open field conditions, decrease mean air temperature by $1{ }^{\circ} \mathrm{C}$, and increase air humidity by 0.05 compared to open field conditions.

Thereby, assumption I is a conservative assumption, which reflects the lower boundary of impacts by shelterbelts on wind speed (cf. [9-11,13,14]). Assumption II reflects the average of the impacts by shelterbelts on climatic features taken from $[9,10,13,14]$.

To estimate the water consumption for the shelterbelt systems versus open field conditions, first ETo and ETc was expressed as evapo-transpiration for a 4 ha $(200 \times 200 \mathrm{~m})$ and a 25 ha $(500 \times 500 \mathrm{~m})$ field plot under open field conditions, under assumption I, and under assumption II, respectively. 
The sap flow results were upscaled to $25 \mathrm{~m}$ of homogenous shelterbelt. In these $25 \mathrm{~m}$, all trees were mapped and their DBH was recorded. Xylem thickness and sapwood area were determined from 25 trees which were selected randomly. DBH and sapwood area yielded the relationship

$$
\text { Xylem area }=0.4301 \mathrm{DBH}^{2}+0.235 \mathrm{DBH}, \mathrm{R}^{2}=0.94
$$

This relationship was used to assess the sapwood area of all trees in the mapped shelterbelt. The sap flow of those $25 \mathrm{~m}$ shelterbelt was calculated in 10 min time steps from the average sap flow density of the three sensor trees. Finally, these sap flow values were summed up to daily sap flow values for hose $25 \mathrm{~m}$ shelterbelt. Based on the sap flow of those $25 \mathrm{~m}$ shelterbelt and on ETo, an average crop coefficient $(\mathrm{Kc})$ was calculated, which was used to assess the water consumption of the shelterbelt during the whole growing season. Under the assumption of square shaped fields, as they were common in Soviet Union shelterbelt systems, there are $800 \mathrm{~m}$ and $2000 \mathrm{~m}$ of shelterbelt that border the 4 ha and 25 ha field, respectively.

\section{Results}

Climate data as used for the ETo and further ETc calculations are shown in Table 3.

Table 3. Climate data and ETo in Karasy Batyr, monthly averages during the growing season 2016.

\begin{tabular}{ccccc}
\hline Month & Temperature $\left({ }^{\circ} \mathbf{C}\right)$ & Relative Air Humidity $(\%)$ & Wind Speed $(\mathbf{m} / \mathbf{s})$ & ETo $(\mathbf{m m} / \mathbf{d})$ \\
\hline 4 & 12.7 & 60 & 2.0 & 3.5 \\
5 & 16.5 & 55 & 2.0 & 4.6 \\
6 & 21.3 & 49 & 1.9 & 5.9 \\
7 & 22.0 & 49 & 2.0 & 5.3 \\
8 & 21.2 & 43 & 2.2 & 5.4 \\
9 & 19.9 & 40 & 2.3 & 4.4 \\
10 & 8.7 & 56 & 2.3 & 2.2 \\
\hline
\end{tabular}

ETo and ETc, for corn as an example, in the course of the growing season are shown in Figure 3 for open field conditions and for the two sets of assumption regarding the impact of shelterbelts on climate data.
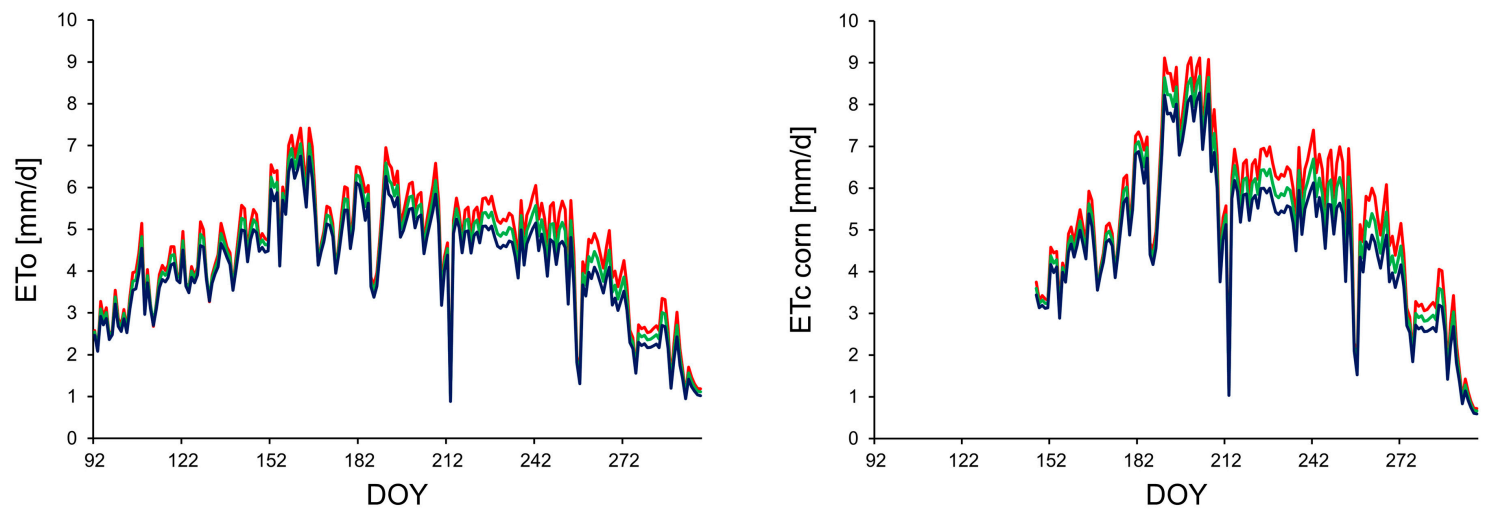

Figure 3. ETo (left) and ETc of corn (right) under open field conditions (in red), under the assumption of reduction of wind speed by $20 \%$ (in green), and under the set of assumptions of reduction of wind speed by $35 \%$, temperature reduction by $1{ }^{\circ} \mathrm{C}$, and increase of air humidity by 0.05 (in blue). DOY refers to $n$th day of the year, i.e., data on the $x$-axis start on 1 April (DOY 92) and end on 24 October.

ETo reaches its maximum in June (7-13 June) with over $7 \mathrm{~mm} / \mathrm{d}$. During these days, air humidity within a given day ranges between 0.18 and 0.6 , which is substantially lower than before and after with values between 0.3 and 0.8 . ETc of corn peaks in July with around $9 \mathrm{~mm} / \mathrm{d}$, when ETo is high and corn is it its mid development stage. 
Regarding ETc over the whole growing season, corn consumes most water (815.1 mm under open field conditions) followed by potato, wheat, and barley (Table 4). Only pears consume more water than corn, $1093 \mathrm{~mm}$ over the growing season under open field conditions (Table 4).

Table 4. ETo and ETc of relevant crops under open field conditions and two scenarios on impact of shelterbelts on micro climate for one growing season each. First scenario: leeward of shelterbelt wind speed is reduced by $20 \%$ compared to open field conditions. Second scenario: leeward of shelterbelt wind speed is reduced by $35 \%$, maximum temperature is decreased by $1{ }^{\circ} \mathrm{C}$, and minimum air humidity is increased by 0.05 compared to open field conditions.

\begin{tabular}{|c|c|c|c|c|c|}
\hline \multirow[t]{2}{*}{ ETo and Crops } & \multirow[t]{2}{*}{$\begin{array}{c}\text { ETo and ETc under } \\
\text { Open Field Conditions }\end{array}$} & \multicolumn{2}{|c|}{$\begin{array}{c}\text { ETO and ETc under } \\
\text { Shelterbelt Assumptions }\end{array}$} & \multicolumn{2}{|c|}{$\begin{array}{l}\text { Difference of ETo and ETc between } \\
\text { Open Field and Assumption }\end{array}$} \\
\hline & & I & II & I & II \\
\hline \multicolumn{6}{|l|}{$\mathrm{ET}(\mathrm{mm})$} \\
\hline ETo & 938.9 & 893.2 & 847.3 & 45.7 & 91.6 \\
\hline Wheat & 611.2 & 586.2 & 561 & 25 & 50.2 \\
\hline Corn & 815.1 & 764 & 717.1 & 51.1 & 98 \\
\hline Potato & 660.7 & 632.2 & 603.6 & 28.5 & 57.1 \\
\hline Barley & 584.7 & 561.4 & 537.2 & 23.3 & 47.5 \\
\hline Fruit trees (pear) & 1093.3 & 1025.3 & 962.4 & 68 & 130.9 \\
\hline \multicolumn{6}{|l|}{ ET for 4 ha field $\left(\mathrm{m}^{3}\right)$} \\
\hline Eto & 37,555 & 35,272 & 33,890 & 1828 & 3664 \\
\hline Wheat & 24,446 & 23,448 & 22,439 & 999 & 2007 \\
\hline Corn & 32,604 & 30,560 & 28,683 & 2044 & 3921 \\
\hline Potato & 26,427 & 25,288 & 24,145 & 1139 & 2238 \\
\hline Barley & 23,388 & 22,456 & 21,486 & 931 & 1901 \\
\hline Fruit trees (pear) & 43,732 & 41,012 & 38,494 & 2720 & 5237 \\
\hline \multicolumn{6}{|l|}{ ET for 25 ha field $\left(\mathrm{m}^{3}\right)$} \\
\hline Eto & 234,717 & 223,291 & 211,816 & 11,426 & 22,901 \\
\hline Wheat & 152,790 & 146,547 & 140,246 & 6243 & 12,544 \\
\hline Corn & 203,778 & 191,001 & 179,269 & 12,777 & 24,509 \\
\hline Potato & 165,172 & 158,052 & 150,906 & 7120 & 14,266 \\
\hline Barley & 146,172 & 140,353 & 134,289 & 5819 & 11,883 \\
\hline Fruit trees (pear) & 273,324 & 256,325 & 240,590 & 16,999 & 32,734 \\
\hline
\end{tabular}

The most pronounced reduction of water consumption through the effect of shelterbelts was observed for pear and corn with a reduction by $12 \%$ and $6 \%$ under the assumption II and assumption I, respectively. As for barley, there is only a reduction of crop water consumption by $8 \%$ under assumption II.

Tree water consumption, as measured from the sap flow sensor trees, is highest for sensor tree 1 , which has the highest DBH $(46.2 \mathrm{~cm})$, followed by sensor tree 3, and 2 (Figure 4). Sensor tree 2 has the lowest DBH with $19.2 \mathrm{~cm}$ (Table 2). Water consumption follows a very similar trend for all trees, despite the huge differences in absolute values of daily water consumption.

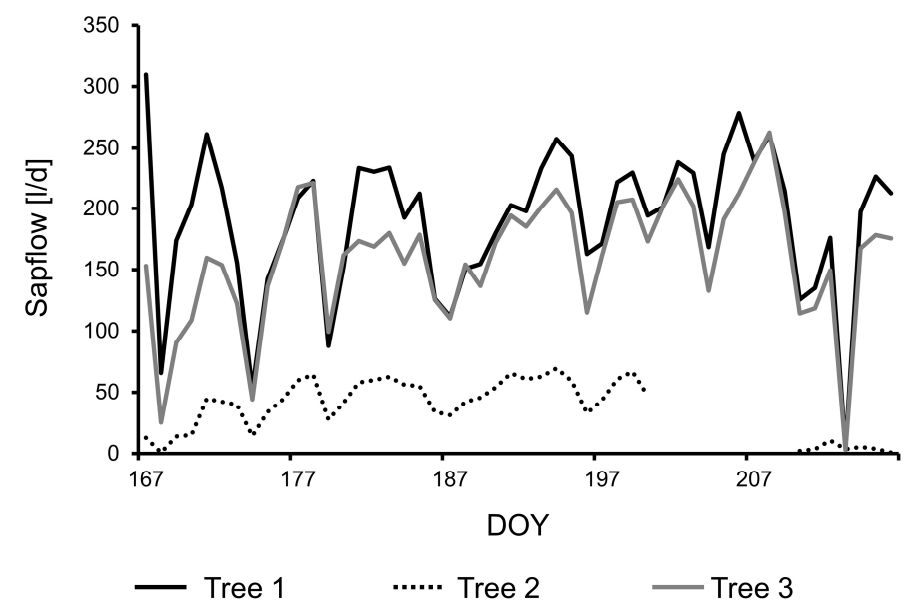

Figure 4. Daily sapflow (L/d) of the three sensor trees from 15 June (DOY 167) to 3 August (DOY 216). DOY refers to $n$th day of the year. 
Also ETo and water consumption of the shelterbelt, as shown in Figure 5, follow a similar trend, with water consumption of the shelterbelt mostly being higher than ETo. From the water consumption of the shelterbelt and ETo an average Kc value of 1.43 was obtained. This Kc value was used, in order to calculate the water consumption of the shelterbelt for the whole growing season. Water consumption per $100 \mathrm{~m}$ shelterbelt was $1297 \mathrm{~m}^{3}$ for the whole growing season.

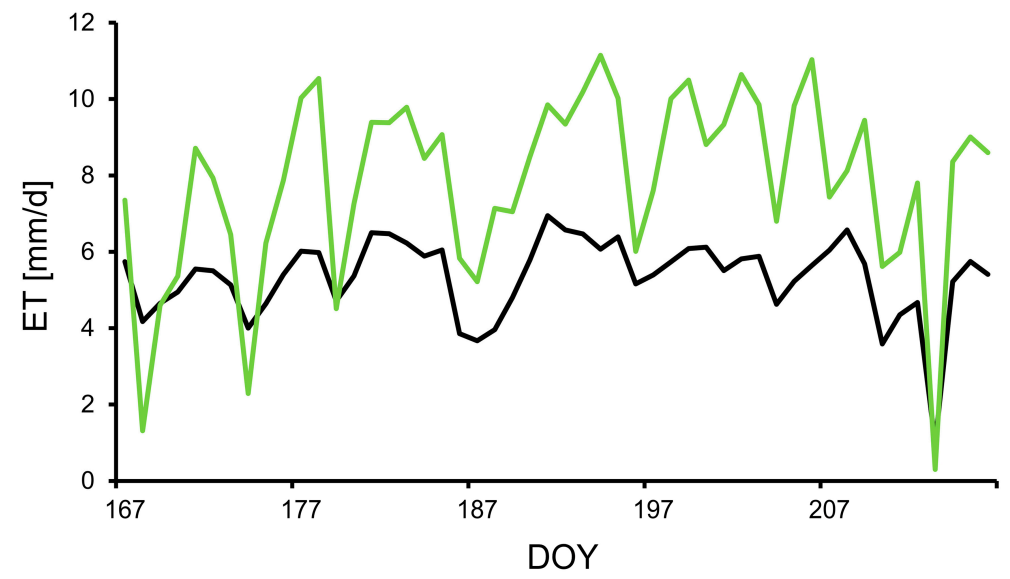

Figure 5. ETo (mm/d) and daily ET (mm/d) of shelterbelt from 15 June (DOY 167) to 3 August (DOY 216). DOY refers to $n$th day of the year.

A square shaped 25 ha field $(500 \times 500 \mathrm{~m})$ is bordered by $2000 \mathrm{~m}$ of shelterbelt, which would consume $25,940 \mathrm{~m}^{3}$ per growing season. As shelterbelts are shared by neighboring fields, for such a $25 \mathrm{ha}$ field a tree shelterbelt water consumption of $12,970 \mathrm{~m}^{3}$ was considered for the growing season. Only corn and pear showed a substantial reduction of water consumption, which overcompensated the tree shelterbelts' water consumption (Table 5), so that a shelterbelt system of corn and pear on 25 ha field plots, respectively, with poplar shelterbelts consumes less water than corn and pear without a shelterbelt system.

Table 5. Water consumption of open field conditions (crop without any shelterbelt) and shelterbelt system (crops and trees) for 4 ha and 25 ha field plot, respectively. Negative differences indicate that the whole shelterbelt system consumes less water than the crop without shelterbelt.

\begin{tabular}{|c|c|c|c|c|c|}
\hline \multirow[t]{3}{*}{ Crop } & \multicolumn{3}{|c|}{ Water Consumption of } & \multirow{2}{*}{\multicolumn{2}{|c|}{$\begin{array}{c}\text { Difference between } \\
\begin{array}{c}\text { Shelterbelt System and Open } \\
\text { Field, Assumptions }\end{array}\end{array}$}} \\
\hline & \multirow[t]{2}{*}{ Open Field } & \multicolumn{2}{|c|}{$\begin{array}{l}\text { Shelterbelt System Including } \\
\text { Trees, Assumptions }\end{array}$} & & \\
\hline & & I & II & $\mathbf{I}$ & II \\
\hline \multicolumn{6}{|c|}{$\begin{array}{l}\text { Water consumption for } 4 \text { ha field } \\
\qquad\left(\mathrm{m}^{3}\right)\end{array}$} \\
\hline ETo & 37,555 & 40,460 & 39,078 & 2905 & 1523 \\
\hline Wheat & 24,446 & 28,636 & 27,627 & 4190 & 3181 \\
\hline Corn & 32,604 & 35,748 & 33,871 & 3144 & 1267 \\
\hline Potato & 26,427 & 30,476 & 29,333 & 4049 & 2906 \\
\hline Barley & 23,388 & 27,644 & 26,674 & 4256 & 3286 \\
\hline Fruit trees (pear) & 43,732 & 46,200 & 43,682 & 2468 & -50 \\
\hline \multicolumn{6}{|c|}{$\begin{array}{l}\text { Water consumption for } 25 \text { ha field } \\
\qquad\left(\mathrm{m}^{3}\right)\end{array}$} \\
\hline ETo & 234,717 & 236,261 & 224,786 & 1544 & -9931 \\
\hline Wheat & 152,790 & 159,517 & 153,216 & 6727 & 426 \\
\hline Corn & 203,778 & 203,971 & 192,239 & 193 & $-11,539$ \\
\hline Potato & 165,172 & 171,022 & 163,879 & 5850 & -1293 \\
\hline Barley & 146,172 & 153,323 & 147,259 & 7151 & 1087 \\
\hline Fruit trees (pear) & 273,324 & 269,295 & 253,560 & -4029 & $-19,764$ \\
\hline
\end{tabular}

A square shaped field of 4 ha $(200 \times 200 \mathrm{~m})$ is surrounded by $800 \mathrm{~m}$ of shelterbelt. $800 \mathrm{~m}$ of shelterbelt would consume $10,376 \mathrm{~m}^{3}$ of water. Analogous to the 25 ha field, a water consumption of $5188 \mathrm{~m}^{3}$ for the growing season is considered, as shelterbelts are shared by neighboring fields. As for 
the 4 ha field plot, the shelterbelt system with crops and trees consumes more water than the crops without shelterbelts, except for pears under the set of assumptions II (Table 5).

\section{Discussion}

Tree water consumption was in the same range as values published by [21] for Poplars in NW China, ranging from 20.1 to $161.4 \mathrm{~kg}$ water per day and per tree. Water consumption of sensor tree no. 1 in this study was higher than values of [21]. This difference can be explained by the bigger DBH and sap wood area of sensor tree no. 1 compared to trees from [21]. ETc values of this study are in the range of other studies, e.g., water consumption of corn with values between $741 \mathrm{~mm}$ and $841 \mathrm{~mm}$ measured in Texas with a lysimeter under sprinkler irrigation [22]. Wheat ETc calculated from climate data from Almaty [23] was the same as wheat ETc under open field conditions of this study. Annual corn water consumption of $668 \mathrm{~mm}$ was found in the Heihe Basin in NW China [24]. This value is lower than ETc of corn under all assumptions in this study, because corn in the Heihe Basin was grown under plastic mulch, which considerably reduced evaporation from the soil surface during the initial crop development stage.

Under the calculations for a hypothetical 4 ha $(200 \times 200 \mathrm{~m})$ field, all crops-shelterbelt systems (except pear) consumed more water than the respective crop without the shelterbelt (Table 4). Only under calculation for the $25 \mathrm{ha}(500 \times 500 \mathrm{~m})$ field plot did corn, potato, and pear show a reduction of water consumption when combined with a shelterbelt. This difference is due to the relatively shorter shelterbelt compared to field area for the 25 ha field plot ( $2000 \mathrm{~m}$ shelterbelt) versus $800 \mathrm{~m}$ shelterbelt around the 4 ha field plot. On the other hand, field plots must not be too large, as the effect of the shelterbelts on wind speed decreases with distance from the shelterbelts and thus decreases with field plot size.

Reduction of ETc under shelterbelts in this study was about 10\% (maximum reduction of ETc was $12 \%$ with pear, cf. Table 3 ). These values are well below the reduction of crop water consumption as suggested by the literature from Soviet Union times [9,10,12,14], but in the range of [11]. This difference might be explained by rather conservative assumptions with respect to the impact of shelterbelts on the micro climate of adjacent field plots. Additionally, some investigations cited here were undertaken in areas that are windier compared to the study site of this paper so that a wind speed reduction has a greater effect on crop water consumption.

With respect to only the water consumption, shelterbelt systems reduce water consumption of corn, potato, and pear, which are crops with a high crop water demand, under the conditions of a square shaped 25 ha field. Under the conditions of a 4 ha field, all crop-shelterbelt systems consume more water (except for pear) than the crop without shelterbelts. So, it can be concluded that shelterbelts around large field plots may play a role to improve water resource management in the context of crops with a high crop water demand, like corn or cotton. In this study, other effects of shelterbelts, like increases of crop yields and additional income from timber and fuel wood, have not been considered. So, if water productivity, which is total income by total water consumption, was compared of the whole crop-shelterbelt system versus crops without shelterbelt, then again a different picture, a more substantial contribution of shelterbelts to improved water resource management, might turn out.

Acknowledgments: This study was undertaken with support from the Federal Ministry of Economic Cooperation and Development of Germany (BMZ), through the Advisory Service on Agricultural Research for Development (BEAF) under Deutsche Gesellschaft für Internationale Zusammenarbeit (GIZ), Germany. BMZ funded a research grant of 100,000 EUR and a six-month internship for Eva Strenge, in order to collect sap flow data. Niels Thevs' position as an integrated expert at the World Agroforestry Center as well as the sap flow equipment and the climate stations were co-funded by BMZ as part of the Center for International Migration and Development (CIM) program.

Author Contributions: Niels Thevs carried out the processing and analysis of climate data for the ETo and ETc calculations together with Maksat Eraaliev. Eva Strange carried out the analysis of sap flow data with supervision from Petra Lang. Kumar Aliev did the necessary tree measurements and tree data analyses. Kumar Aliev, Maksat Eraaliev, and Azim Baibagysov contributed to the literature review, in particular through review of the Russian literature. Jianchu Xu did some editing.

Conflicts of Interest: The authors declare no conflict of interest. 


\section{References}

1. MEA (Millennium Ecosystem Assessment). Ecosystems and Human Well-being: Synthesis; Island Press: Washington, DC, USA, 2005.

2. Karthe, D. Environmental Changes in Central and East Asian Drylands and their Effects on Large Central and East Asian Lakes and their Effects on Major River-Lake Systems. Quat. Int. 2017. [CrossRef]

3. UNEP (United Nations Environment Programme). 2004. Available online: http://www.grid.unep.ch/ activities/sustainable/balkhash/ (accessed on 20 November 2016).

4. Micklin, P. The future Aral Sea: Hope and despair. Environ. Earth Sci. 2016, 75, 1-15. [CrossRef]

5. CACILM (Central Asian Countries Initiative for Land Management); ADB (Asian Development Bank). Central Asia Atlas of Natural Resources; CACILM and ADB: Manila, Philippines, 2010. Available online: http:/ / www.adb.org/sites/default/ files/publication/27508/central-asia-atlas.pdf (accessed on 2 July 2015).

6. Unger-Shayesteh, K.; Vorogushyn, S.; Farinotti, D.; Gafurov, A.; Duethmann, D.; Mandychev, A.; Merz, B. What do we know about past changes in the water cycle of Central Asian headwaters? A review. Glob. Planet. Chang. 2013, 110, 4-25. [CrossRef]

7. Feike, T.; Mamitimin, Y.; Li, L.; Abdusalih, N.; Doluschitz, R. Development of agricultural land and water use and its driving forces in the Aksu-Tarim Basin, P.R. China. Environ. Earth Sci. 2015, 73, 517-531. [CrossRef]

8. Rumbaur, C.; Thevs, N.; Disse, M.; Ahlheim, M.; Brieden, A.; Cyffka, B.; Duettmann, D.; Feike, T.; Frör, O.; Gärtner, P.; et al. Sustainable management of river oases along the Tarim River (SuMaRiO) in Northwest China under conditions of climate change. Earth Syst. Dyn. 2015, 6, 83e107. [CrossRef]

9. Albenskii, A.V.; Kalashnikov, A.F.; Ozolin, G.P.; Nikitin, P.L.; Surmach, G.P.; Kulik, N.F.; Senkevich, A.A.; Kasyanov, F.M.; Pavlovskii, E.S.; Roslyakov, N.V. Agroforestry Melioration; Lesnaya Promyshlennost: Moscow, Russia, 1972.

10. Vasilyev, M.E. Melioration through Forests and Harvest; Kainar: Almaty, Kazakhstan, 1980.

11. Alemu, M.M. Ecological Benefits of Trees as Windbreaks and Shelterbelts. Int. J. Ecosyst. 2016, 6, 10-13. [CrossRef]

12. Perry, C.H.; Woodall, C.W.; Liknes, G.C.; Schoeneberger, M.M. Filling the gap: improving estimates of working tree resources in agricultural landscapes. Agrofor. Syst. 2009, 75, 91-101. [CrossRef]

13. Stepanov, A.M. Agroforestry Melioration in Irrigated Lands; Agropromizdat: Moscow, Russia, 1987.

14. Dokuchaev Scientific Research Institute of Agriculture. Agroforestry Melioration of Vegetable Cultures and Potato; Voronesh Publishing House: Voronesh, Russia, 1961.

15. Susa, N.I. Agroforestry Melioration; Governmental Publishing House for Agriculture: Moscow, Russia, 1959.

16. Kainar. Agroforestry in Kazakhstan; Kainar: Almaty, Kazakhstan, 1983.

17. Bulychev, A.S.; Onishenko, L.P. Use and Effectiveness of Tree Shelterbelts in Chui Valley; Advisory Report of the Forestry Committee to the Ministries of the Kyrgyz SSR; Publishing House "Kyrgyzstan": Frunze, Kyrgyzstan, 1979.

18. Allen, R.G.; Pereira, L.S.; Raes, D.; Smith, M. Crop Evapotranspiration-Guidelines for Computing Crop Water Requirements; FAO Irrigation and Drainage Paper 56; FAO: Rome, Italy, 1998.

19. Granier, A. Evaluation of transpiration of in a Douglas fir stand by means of sap flow measurements. Tree Physiol. 1987, 3, 309-320. [CrossRef] [PubMed]

20. Lubczynski, M.W.; Chavarro-Rincon, D.; Roy, J. Novel, cyclic heat dissipation method for the correction of natural temperature gradients in sap flow measurements. Part 1. Theory and application. Tree Physiol. 2012, 32, 894-912. [CrossRef] [PubMed]

21. Chang, X.X.; Zhao, W.Z.; Zhang, Z.H.; Su, Y.Z. Sap flow and tree conductance of shelter-belt in arid region of China. Agric. For. Meteorol. 2006, 138, 132-141. [CrossRef]

22. Howell, T.A.; Tolk, J.A.; Schneider, A.D.; Evett, S.R. Evapotranspiration, yield, and water use efficiency of corn hybrids differing in maturity. Agron. J. 1998, 90, 3-9. [CrossRef] 
23. Thevs, N.; Nurtazin, S.; Beckmann, V.; Salmurzauly, R.; Akimalieva, A. Water consumption of agriculture and natural ecosystems along the Ili River in China and Kazakhstan. Water 2017, 9, 207. [CrossRef]

24. Hochmuth, H.; Thevs, N.; He, P. Water allocation and water consumption of irrigation agriculture and natural vegetation in the Heihe River watershed, NW China. Environ. Earth Sci. 2015, 73, 5269-5279. [CrossRef]

(C) 2017 by the authors. Licensee MDPI, Basel, Switzerland. This article is an open access article distributed under the terms and conditions of the Creative Commons Attribution (CC BY) license (http://creativecommons.org/licenses/by/4.0/). 